\title{
Botanical Pharmacognosy of Holostemma ada-kodien Schult.
}

\author{
Sudhakaran Madathilparambil Vasu*
}

\section{Sudhakaran Madathilparambil \\ Vasu* \\ UGC Academic Staff College, University of Calicut, Calicut University PO, Malap- puram -673635, Kerala, India.}

\section{Correspondence}

M.V. Sudhakaran

UGC Academic Staff College, University of Calicut, Calicut University PO, Malappuram -673635, Kerala, India.

Phone: 91- 471-2555125;

Mob: 9447500125

E-mail: dr.sudhakaranvasu@gmail.com, dr.sudhakaranvasu@yahoo.co.in

\section{History}

- Submission Date: 27-9-2016

- Review completed: 12-12-2016;

- Accepted Date: 20-12-2016.

DOI : 10.5530/pj.2017.2.27

Article Available online http://www.phcogj.com/v9/i2

\section{Copyright}

(C) 2017 Phcog.Net. This is an openaccess article distributed under the terms of the Creative Commons Attribution 4.0 International license.

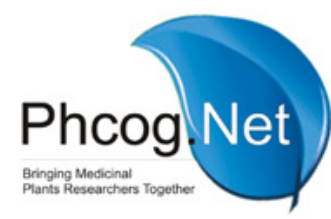

\begin{abstract}
Background: Holostemma ada-kodien Schult. is a perennial, twinning, laticiferous climbing herb belongs to the family Asclepiadaceae. It is an important medicinal plant with rejuvenate properties, used in Ayurveda for promoting vitality and life. The roots are sweet, ophthalmic, emollient, aphrodisiac, expectorant and galactagogue. It is highly specialized for the richness of a diverse array of aminoacids such as alanine, aspartic acid, glycine, serine, thereonine, valine, and terpenoid sugars. Aim: The present study was performed with the objectives of elaborating the macroscopic and histo-morpho diagnostic profile of Holostemma ada-kodien and analyse the quantitative, and powder microscopic peculiarities to support its pharmacognostic characterization. Materials and Methods: microscopic evaluation, quantitative standards and powder microscopy were carried out using the stem, root tuber, root and leaves. Results: Distribution of uniseriate, tricellular clothing trichomes in the epidermal tissues of the midrib, entire leaf margin with campylodromous major venation pattern, amphistomatic epidermis with anisocytic stomata, dorsiventral differentiation of mesophyll, small palisade ratio, small stomatal index, and the vascular system with several free collateral bundles in the petiole were features characteristic of the species. Gelatinous fibers distributed as concentric 'white rings' in the cortical tissues of the stem as distinct groups, deposition of druses crystals of calcium oxalate in the epidermal tissues of the lamina, ground tissues of petiole, cortical tissues of stem, root, root tubers and parenchymatous pith of the stem. Secondary xylem appeared fissured as radial and tangential strips, like the spokes of a wheel in cross section of the root tuber. Xylem core seemed irregular and wedge shaped in the mature root, with more axial and radial parenchyma and less xylem fibers also features characteristic of the taxon.
\end{abstract}

Key words: Anisocytic stomata, gelatinous fibres, druses crystals, compound starch grains, stone cells.

\section{INTRODUCTION}

Holostemma ada-kodien Schult. (Syn. H. annulare (Roxb.) K. Schum.) is a perennial, twinning and climbing herb belongs to the family Asclepiadaceae. The generic name is derived from the Greek holo means 'whole or entire' and stemma means a 'garland or crown' alludes to the staminal crown and the specific epithet annulare in Latin means with a ring (annulus $=$ ring) probably referring to the vertical bars on the petals. The plant is native of Indo-China, Myanmar, Burma, Nepal, Pakistan and Sri Lanka. In India the plant is so widely distributed in tropical rain forest, and quite common in Kerala and Tamil Nadu. Holostemma ada-kodien is an important medicinal plant with rejuvenate properties used in Ayurveda for promoting vitality and life. The root tuber of $\mathrm{Ho}$ lostemma ada-kodien Schult, is much acclaimed in the South Indian traditional Rasayana (tonic) drugs, which often considered as the source of Jivanti (jiva $=$ life or liveliness). Rasayana which literally means the path (ayana) that the rasa (tissue or plasma) takes; in other words the qualities of rasa-dhatu of the drug sway the health of other dhatus of the body. Rasayana therapy is one of the major streams of Ayurvedic medicinal practice used since ancient times to vitalize, nourish and rejuvenate the body, thus improves the general health. Ayurveda classical texts attribute high medicinal values to Jivanti. According to Khare, ${ }^{1}$ the Charaka and Bhaavaprakaasha described Jivanti as Shaakashreshtha (the best among leafy vegetables); an agent for spermatogenesis and galactagogue by Sushruta, and rejuvenating tonic by Charaka. Bhaavaprakaasha, Dhanvantari Nighantu and Kaiyadeva Nighantu had been ascribed to it being the vision promoting properties. Vagbhata included jivanti in Jivaniya gana, ${ }^{2}$ which constitute a vitalizing group of ten such drugs, and the drug had find mention even in the Atharva Veda (about 4500 to $1600 \mathrm{BC}$ ).

Jivanti is one of the most important ingredients in several traditional poly herbal formulations of the Indian system of medicine, such as Ashoka Gharita, Ashwagandhadi Gharita, Anu Thaila. ${ }^{2-3}$ The plant parts when gently bruise yield white latex exudate. The roots are sweet, ophthalmic, emollient, aphrodisiac, expectorant, galactagogue and cure tridosha ${ }^{4}$. It also used to cure the nausea, ulcers, itching, leucoderma, and vesicular calculi. The plant is highly specialized for the richness of a diverse array of amino acids such as alanine, aspartic acid, glycine, serine, thereonine, valine. The alpha amyrin, sitosterol and tepanoid sugars present in the tuberous roots are ascribed for having the medicinal properties. ${ }^{5}$ Reddy et 
al. ${ }^{6}$ have elucidated the anti-diabetic property of the root tuber against the induced diabetes mellitus in rat model. The plant is also being reported to have pronounced antibacterial, antipyretic, anthelminthic, hepatoprotective and hypoglycemic effects. ${ }^{7-10}$ In Ayurvedic treatment regime several plant species are often found used to make the Jivanti drug by physicians from different parts of India. They include species such as Leptadenia reticulata (Retz.)Wight \& Arn. (in Rajasthan); Desmotrichum fimbriatm Blume, Dendrobium macraei Landl. (in West Bengal); Dregea volubilis (L.f.) Benth. ex Hook.f.; Sarcostemma brevistigma Wight \& Arn and Flickingeria nodosa (Dalzell) Seidenf. The root of Holostemma adakodien Schult. is known as the drug Jivanti in southern parts of India, including Kerala ${ }^{11}$.

The objectives of the present work was to characterize morphologically and histologically the root tuber, root, stem, lamina, epidermal peel, mid vein, petioles and powder microscopic characteristics of Holostemma ada-kodien Schult., using the techniques of digital and polarizing microscopy. It also aims to delineate and establish pharmacongostic markers which may reach some of the important targets regarding the regulatory aspects of quality control measures and also help to distinguish the source drug from the allied, spurious and adulterant species. By safeguarding the process of raw materials identification, the use of genuine raw materials in herbal medicines ameliorate the quality of the preparations and also enable to establish of a bioassay system that permit the identification of bioactive fractions with desired therapeutic efficacy.

\section{MATERIALS AND METHOD}

\section{Materials}

It is a perennial extensively twinning shrub, faintly reddish-green coloured slender stem tend to twist severely around its support, and considered as the remarkable feature of the taxon (Figure 1). The plant exudates milky latex that flows rapidly when cut. The length of the pedicel is longer than peduncle. Leaves: leaves are simple arranged in opposite, lamina obovate- oblong, deeply cordate at the base, acute at the apex, glabrous on both sides (Figure 1b). Inflorescence: cymose, flowers are axillary, white- creamy with red to deep purple at the centre. Corolla: petals five, and fleshy, corona 5 lobed. Stamen 5 , attached to corolla tube, filaments connate with stigmatic head to form the gynostegium with a five angled disc. Ovary: two, each carpel containing numerous ovules. Opening of flowers occurred between 20-24 days after the bud initiation. Fruit: two lobed or paired thick follicles. Each follicle contains numer-

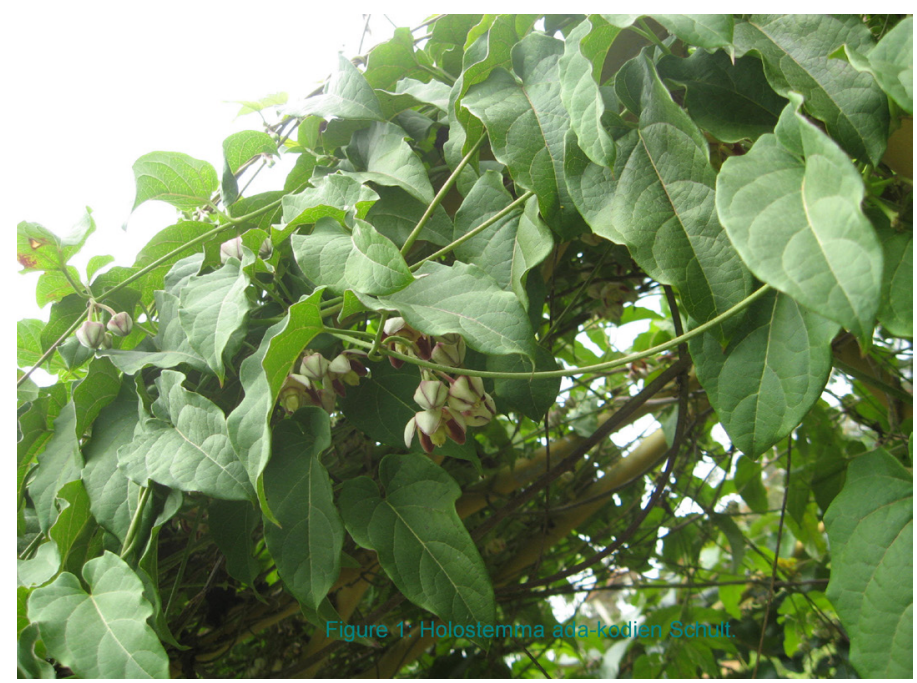

Figure 1: Holostemma ada-kodien Schult. ous, ovoid seeds, with a tuft of silky hairs at each ends. Seeds dispersed by wind.

\section{Methods}

Holostemma ada-kodien Schult. was collected from the Thiruvananthapuram District of the State of Kerala and identification and authentication were done using Gamble's Flora of Presidency of Madras. Fine hand sections of lamina, petiole, stem, root and epidermal peels were taken using standard procedures and stained with aqueous Safranin $1 \%$ and mounted in glycerin. The investigation on macroscopic, micro-morpho diagnostic profile, analysis of quantitative, and powder microscopic properties of the specimens were undertaken. Microphotographs of sections and powder analysis were made by using Olympus Microscope(Model CX 41; Tokyo, Japan) with CCD camera 2 mega pixel and quantitative measurements were taken using Olympus Image-Pro Plus, version 5.1 software. The number of epidermal cells, stomatal number, stomatal index were calculated per square millimetre of leaf area from intercostal areas of fresh leaves as defined by Salisbury and palisade ratio was determined based on Wallis ${ }^{12}$ and size of Guard Cell Area (GCA) was estimated following Franco's formula. ${ }^{13}$ The descriptive terms of the anatomical features used here as per Hickey, ${ }^{14}$ Metcalfe and Chalk, ${ }^{15}$ Carlquist $^{16}$ and Sudhakaran. ${ }^{17-19}$

\section{Microscopic evaluation of root tuber}

The taproots are slender, branched and swollen at intervels. The root tuber were white in colour and appered as nodulated, flatted cylinder, tapered towards both ends (Figure 1c). Root tubers were appeared intermitant at places on the main tap root system. T.S of root tuber seemed irregularly circular in outline with tissue organizaton as outer cork, middle cortex and inner secondary xylem. The conspicuous cork was composed of 10-15 layers. Outer 4-6 layers were thick walled, cells filled with reddish brown content, followed by $6-7$ layers of thin walled, square or rectangular cells. Cells were devoid of contents and appered white in color. Cortex was very prominent and consituted the major portion of the root tuber (Figure $2 \mathrm{~b}$ ). Cortex was differentiated into two distinct zones; the outer and inner cortex. Cells of the outer cortex contained druses

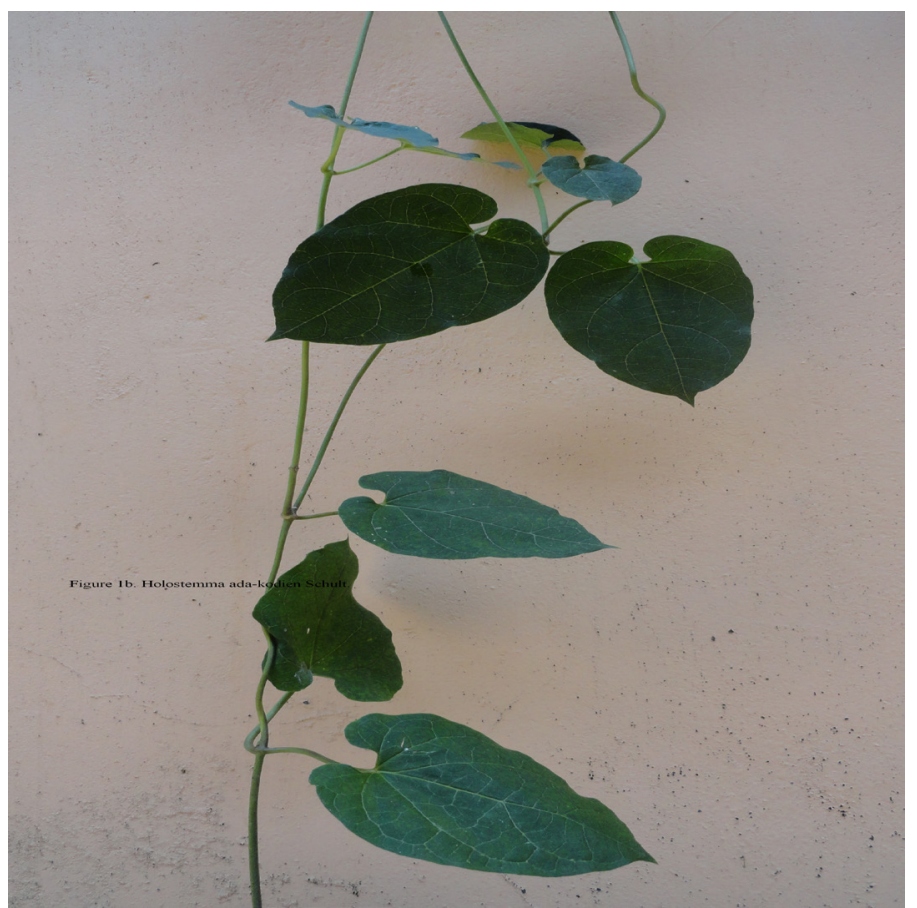

Figure 1 b: Holostemma ada-kodien Schult. A twig 


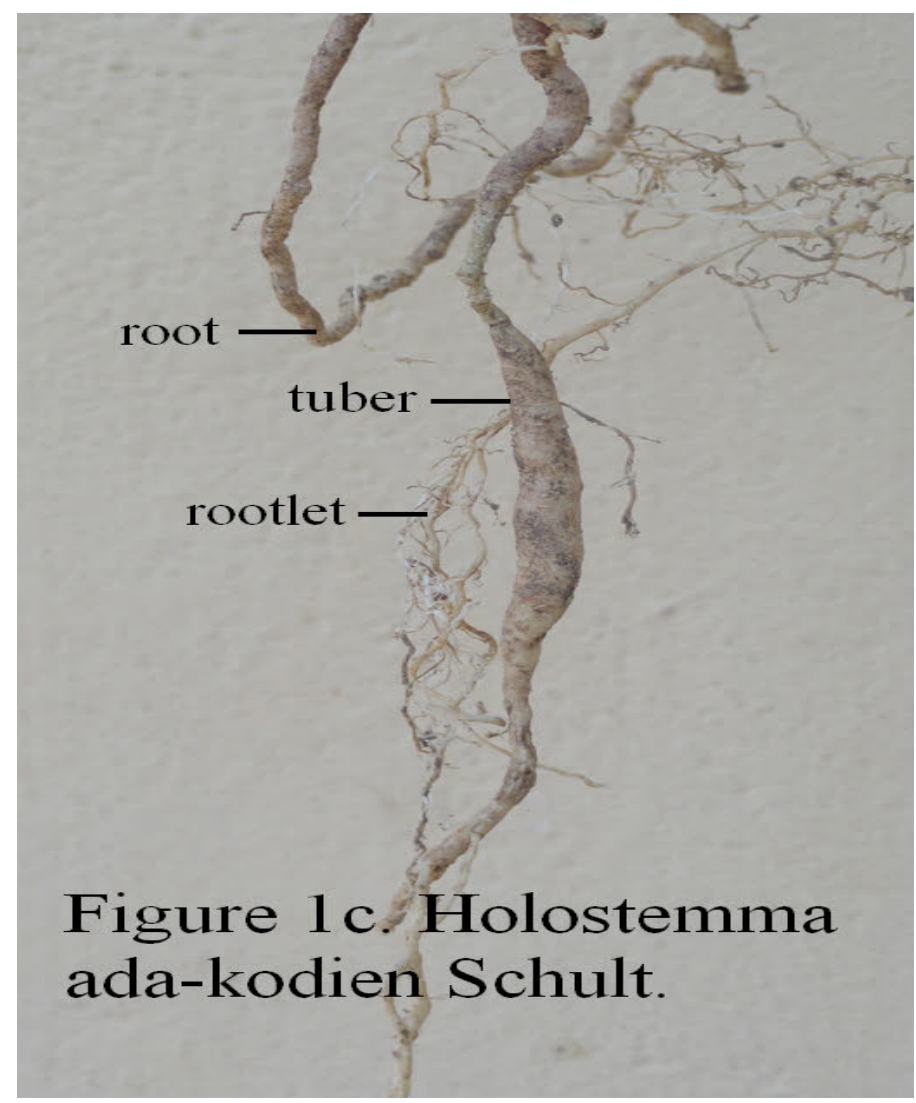

Figure 1c: Holostemma ada-kodien Schult. Root tuber

crystals of calcium oxalate. The crystals varied in size, ranged from 30 to $45 \mu \mathrm{m}$ in length and 27 to $32 \mu \mathrm{m}$ in diameter. Beneath the outer parenchymatours cortex, 8-10 rows of cells interior, traversed by a layer of stone cells. Stone cells were rectangular to pentagonal in shape, aligned more or less contineous as a boken ring in the cortex. Each group consisted of 2-3 stone cells, with a broad band of parenchymatous tissues intervening between the group of sclereids. The stone cells were lignified, striated and pitted with wide lumen (Figure 2e). Cortical cells were filled with plenty of starch grains, which composed of both simple and compound grains (Figure $2 \mathrm{f} \& 2 \mathrm{~g}$ ). Wood constituted to form a narrow zone. When cross sectioned at the tapered end portion of root tuber, the secondary xylem appeared fissured and arranged like spokes of a wheel (Figure $2 \& 2 a$ ), where the narrow band of xylem strips began to develop from the cambium and gradually broadened, run horizontally towards the center. While the sections taken from the middle portion of the root tuber, showed secondary xylem as a closed round to elliptico-ovoid ring like configuration (Figure $2 \mathrm{c} \& 2 \mathrm{~d}$ ) at the center and the xylem appeared forked dichotomously towards the periphery, aligned conspicuously two separate ' $v$ ' shaped configurations (Figure 2d), leaving the center of the root tuber devoid of any xylem tissues. Xylem rays were broad, many cells wide and lacked the vessel contacts. Vessels were mostly solitary and small sized, majority of them were arranged in radial rows (Figure $2 \mathrm{~d}$ ). Diameter of xylem vessel lumen ranged from $12.61 \mu \mathrm{m}$ to $39.6 \mu \mathrm{m}$ in size. The number of xylem vessel was not many, larger and smaller vessels were seemed aligned intermittently.

\section{Microscopic evaluation of root}

The tap roots were thin, elongated and cylindrical about $2-3 \mathrm{~mm}$ in diameter and appeared white in colour (Figure 1c). T.S of the root appeared somewhat circular in outline and often ruptured at places with the formation of cork cells (Figure 3, 3c \& 3d). The tissue organization of the root was appeared similar to that of the root tuber. It consisted of

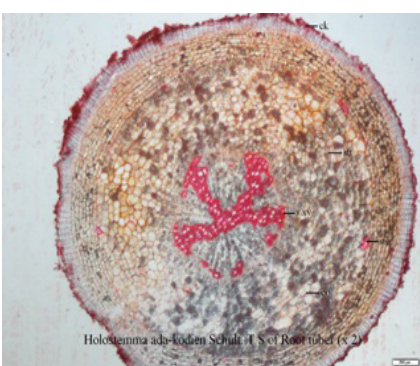

Figure 2: Holostemma ada-kodien Schult. T.S. of root tuber $(\times 2)$.

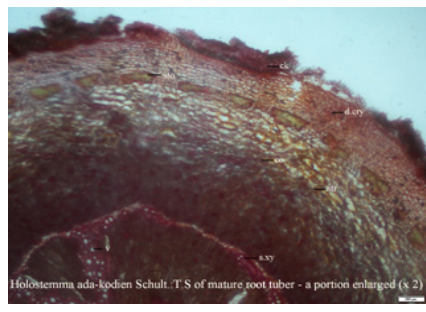

Figure $\mathbf{2 b}$ : Holostemma ada-kodien Schult.T.S. of mature root tuber- a portion enlarged $\times 2$ ).

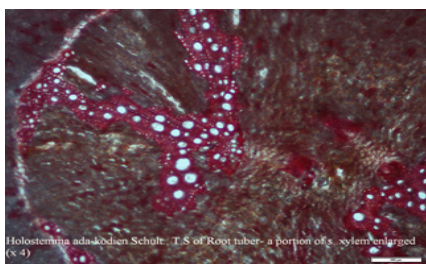

Figure 2d: Holostemma ada-kodien Schult. a portion of root showing secondary xylem (x 40).

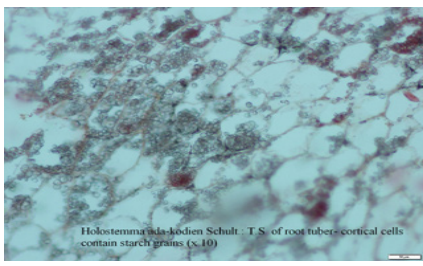

Figure 2f: Holostemma ada-kodien Schult. T.S of root tuber-cortical cells contain starch grains (x 10)

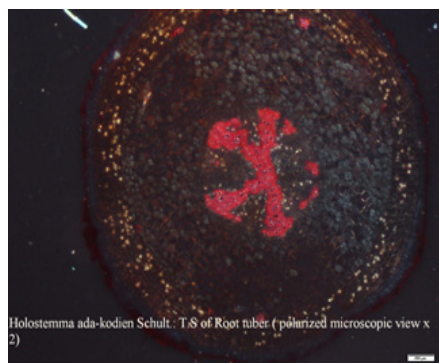

Figure 2a: Holostemma ada-kodien Schult.T.S.of root tuber (polarized microscopic view $\times 2$ ).

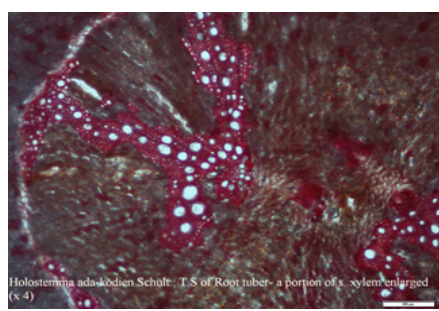

Figure 2c: Holostemma ada-kodien Schult.T.S of root tuber (middle portion enlarged $(\times 2)$.

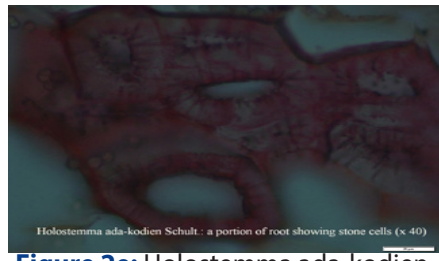
Schult. a portion of root tuber showing stone cells ( $x 40)$.

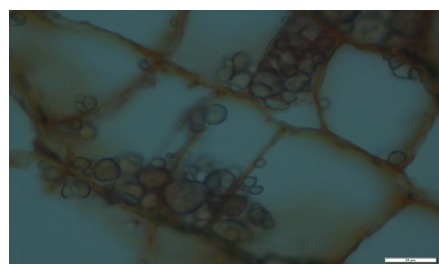

Figure 2g: Holostemma ada-kodien Schult. T.S of root tuber showing starch grains $(x 40)$
Figure 2e: Holostemma ada-kodien

three distinct zones, the outer zone constituted as cork, middle cortex and secondary xylem at the centre. The conspicuous cork consisted of 4-8 rows of elongated rectangular cells, outer most 2-3 layers were filled with brown coloured contents, the inner cork cells were empty and appeared white in colour. Cortex was differentiated to two distinct zones; the outer and inner cortex composed of many layered parenchymatous cells. Outer cortical parenchyma cells contained druses crystals of calcium oxalate. Inner cortical cells comprised of patches or group of stone cells (Figure 3b, 3d, 3e \& 3f). Each group consisted of 2-3 layers of cells. Cortical parenchyma cells were filled with plenty of starch grains. The starch grains were of simple and compound types. Compound type was consisted of three cells. Secondary xylem formed of a narrow band of tissues and occupied at the centre portion, in immature root (Figure 3, $3 a)$.Whereas, the secondary xylem was fissured, xylem core appeared irregular and wedge shaped in the mature root. Wood consisted of more axial and radial parenchyma cells and less xylem fibers. Medullary rays were broad; many cells wide, cells were radially elongated, rectangular and parenchymatous. Vessels were mostly solitary and small sized, ma- 


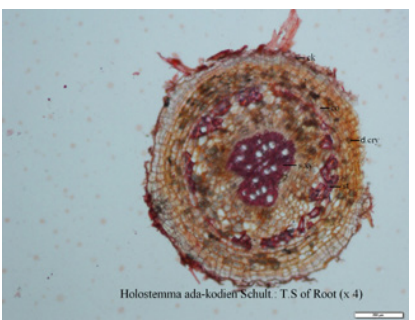

Figure 3: Holostemma ada-kodien Schult. T.S of root (x 4)

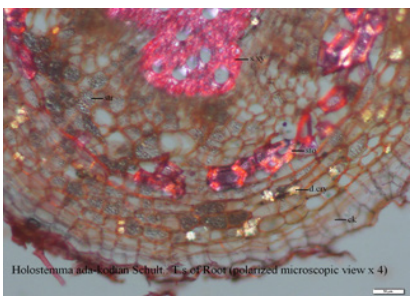

Figure 3b: Holostemma adakodien Schult. T.S of mature roota portion enlarged $(x 4)$

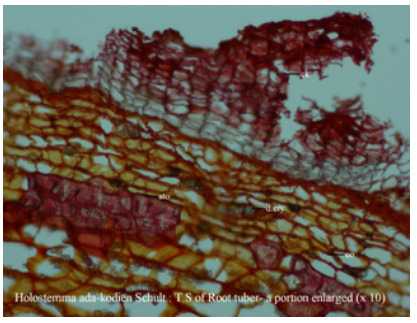

Figure 3d: Holostemma adakodien Schult. T.S of mature roota portion enlarged ( $x$ 10)

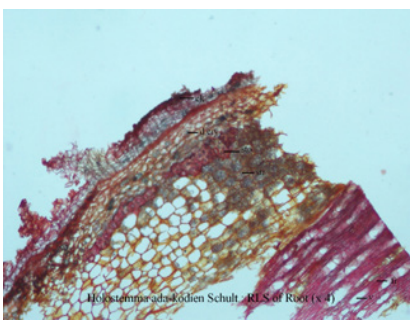

Figure 3f: Holostemma ada-kodien Schult. RLS root ( $x$ 4)

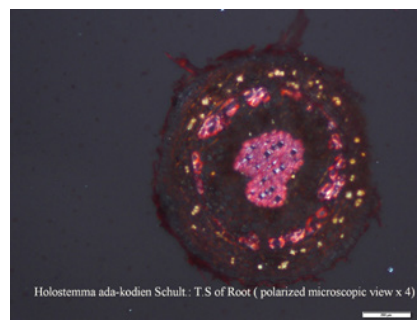

Figure 3a: Holostemma ada-kodien Schult. T.S of root (polarized microscopic view $\times 4$ )

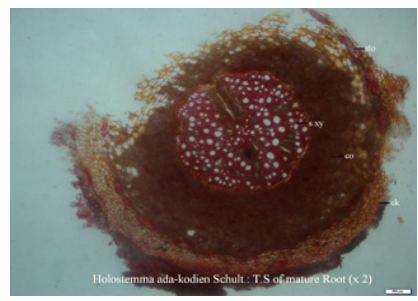

Figure 3c: Holostemma adakodien Schult. T.S of mature root (x 2)

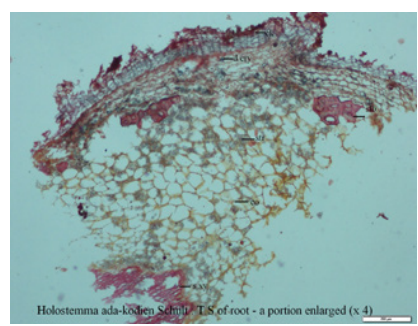

Figure 3e: Holostemma adakodien Schult. T.S of mature roota portion enlarged $(x 4)$

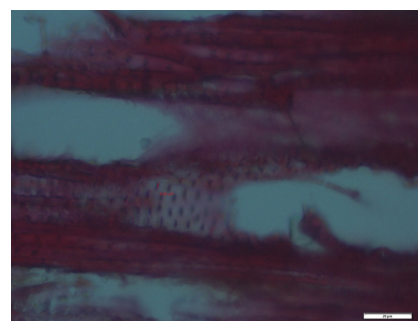

Figure 3g: Holostemma adakodien Schult. RLS root showing intervessel pits ( $x$ 40)

jority of them were arranged in radial rows. Intervessel pits were in alternate position with pit aperture having a mean diameter of about 3.7 $\mu \mathrm{m}$ (Figure 3g).

\section{Microscopic evaluation of stem}

T.S of the stem appeared circular in outline with the margin ruptured at places by the presence of tenticels (Figure $4 \& 4 \mathrm{~b}$ ). Cork formed a narrow zone, comprised 3-4 rows of thick walled rectangular cells, followed by 2-4 layers of thin walled cells. Inner to phellogen were occupied the multilayered secondary cortex. Cortex was broad and wide; occupying several rows of parenchymatous cells. The most remarkable feature of the inner cortex was the presence of several bands of concentric rings of sclerenchyma cells called Gelatinous fibers (G fibers). They were unlignified and appeared as transparent 'concentric white ring' in the cross sections of stem (Figure $4 \mathrm{a} \& 4 \mathrm{c}$ ). The wall of normal wood fiber usually constituted of the primary $(\mathrm{P})$ cell wall layer cemented together by peptic substances of the middle lamellae, followed by successive three secondary

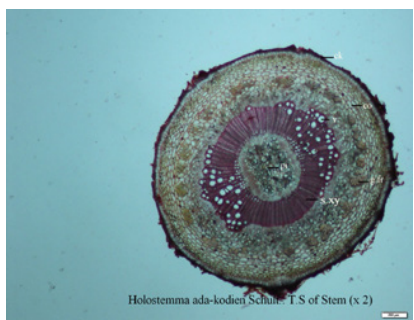

Figure 4: Holostemma ada-kodien Schult. T.S of $\operatorname{stem}(\times 2)$

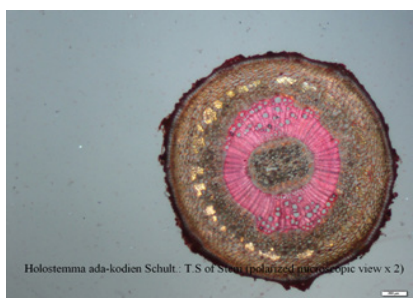

Figure 4b: Holostemma adakodien Schult. T.S of stem (polarized microscopic view $\times 2$ )

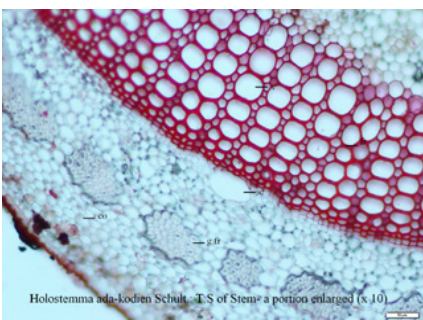

Figure 4a: Holostemma adakodien Schult. T.S of stem- a portion enlarged (x 10)

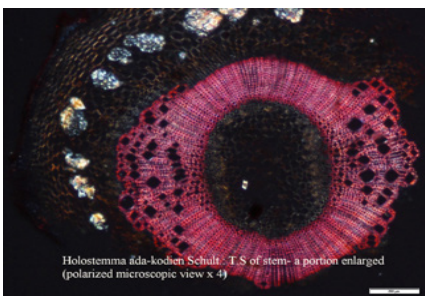

Figure 4c: Holostemma ada-kodien Schult. T.S of root (polarized microscopic view $x$ 4)

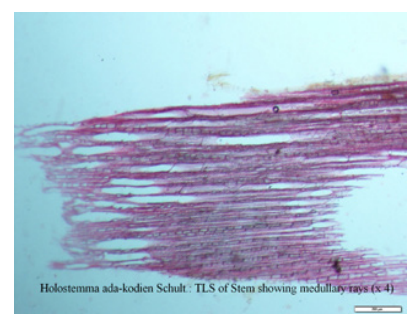

Figure 4d: Holostemma adakodien Schult. TLS of stem showing medullary rays $(x 4)$ wall layers (S1, S2, S3). According to Gorshkor et al. ${ }^{20}$ the cell wall of a mature gelatinous fibre has layers of three distinct types: the pectin-rich P-layer; a variable number (usually one to three) of S-layers, and a tertiary G-layer. As the G layer laid down that precedes the deposition of S layers, thus $\mathrm{G}$ layer often considered as a tertiary. The G-layer reported to have constituted with a high content of crystalline hydrophilic cellulose, low hydroscopic lignin and are loosely attached to other cell wall layers of the fibre..$^{20-21}$ The weak interaction of this layer with most histological stains owing to the high content of crystalline cellulose and reduced lignin biosynthesis make the G-layer remained unstained by safranine (Figure 4a). In contrast to the normal wood fibers, the lignin content in gelatinous fibers is found to be very low. This is because according to Jin and Kwon ${ }^{22}$ that the gene encoding laccases, which could involve in the polymerization of monolignols to produce lignin molecules were reported to be significantly down regulated during cell wall synthesis of $G$ fibres. Further Hu et al. ${ }^{23}$ based on their studies in transgenic trees have reported that the repression of lignin biosynthesis that promotes the crystalline cellulose accumulation in wood fibers. The gelatinous fibers have extensively been implicated for generating mechanical bending in Lianas by many investigators. ${ }^{24-25}$ The gelatinous fibers present in the stem cortex of Holostemma ada-kodien, confers the plant the mechanical ability to twin over the support or fix the stem severely in coiled position. The individual patch or band of gelatinous fibers in cortex often covered an area ranged from $45 \mu \mathrm{m}^{2}$ to $410 \mu \mathrm{m}^{2}$ The G fibers were appeared strongly birefringent (Figure $4 \mathrm{~b} \& 4 \mathrm{c}$ ) under the polarized microscopy, because their wall constituents of microfibrils contain crystalline cellulose, which is birefringent and appears as bright in microphotographs. Cells of the cortex were also provided with plenty of druses crystals of 
calcium oxalate and size of individual crystal ranged from $18.7 \mu \mathrm{m} 48.9$ $\mu \mathrm{m}$ in diameter.

\section{Secondary xylem of stem}

Wood was very prominent and occupied in the middle portion of the stem. The bulk of the wood was constituted by thick walled xylem fibers. Medullary rays were very conspicuous and the abundance of ray parenchyma cells between xylem strands provides great flexibility to the stem during climbing and of twisted growth. Medullary rays were mostly uniseriate and biseriate (Figure $4 \mathrm{~d}$ ). Secondary xylem consisted of a few vessels, mostly confined to two lateral wings- like extensions (Figure 4 \& 4c). Vessels were mostly solitary, ovoid to polygonal in shape, vessels grouping of radial multiple of three were occasionally found. Diameter of vessel lumen ranged from $18.6 \mu \mathrm{m}$ to $60.3 \mu \mathrm{m}$, with a mean diameter of $40.2 \mu \mathrm{m}$. Vessels were having spiral thickening and bordered pits, inter vessel pitting were in alternate position. Lianas tend to have wide xylem vessels which offer ease of water conduits in the stem with low friction and deliver a larger volume of water per unit time. ${ }^{26}$ Pith was centrally placed (Figure 4) and perenchymatous. Parenchymatous cells of the pith contained druse crystals of calcium oxalate.

\section{Microscopic evaluation of leaves}

The leaf of Holostemma ada-kodien Schult. is mesophyll, which consisted of an average length of $10.5 \mathrm{~cm}$ and width of $6.2 \mathrm{~cm}$ (Figure 1b). Leaves have no characteristic taste and odour. Lamina was dorsiventrally differentiated and consisted of epidemics, mesophyll and vascular tissues. Both epidermes were uniseriate, composed of compactly arranged oval to rectangular cells with moderately cuticularized outer walls. Some of the epidermal cells at the midrib were provided with long uniseriate, three celled clothing trichomes. The basal cell of trichome appeared short, having conspicuous lumen and elongated terminal cell which tapered towards the apex. According to Wagner, ${ }^{27}$ the trichomes of the plants serve several functions such as reflecting radiation, lowering plant temperature, reducing water loss and act as the physical and chemicals defences against herbivores. The mesophyll was differentiated into upper palisade and lower spongy tissues (Figure 5a). Palisade appeared as a single row of elongated, barrel shaped of cells. Cells of the palisade

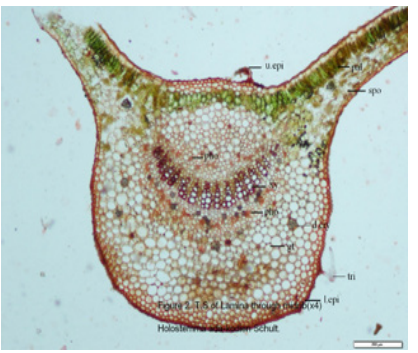

Figure 5: Holostemma ada-kodien Schult. T.S. of Lamina through midrib(x 4)

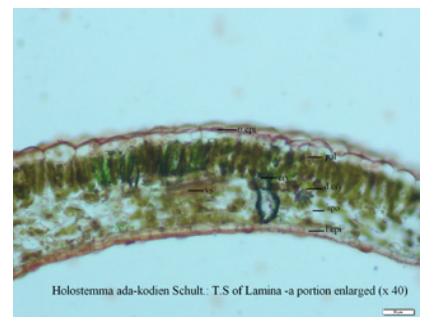

Figure 5b: Holostemma adakodien Schult. T.S. of Lamina- a portion enlarged $(x 40)$

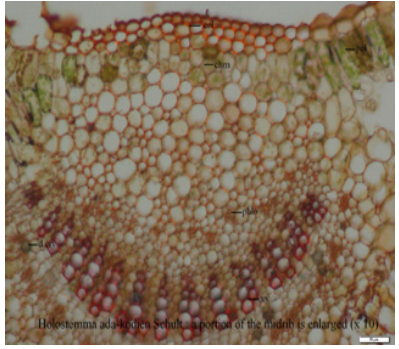

Figure 5a: Holostemma adakodien Schult. a portion of midrib is enlarged ( $x 10)$

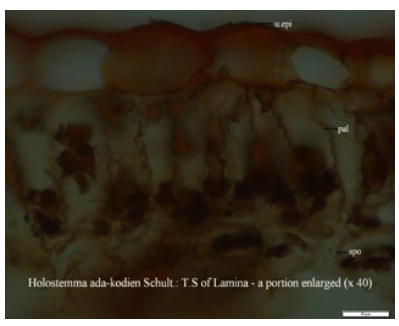

Figure 5c: Holostemma adakodien Schult. T.S. of Lamina- a portion enlarged $(x 40)$

were compactly arranged and filled with plenty of chloroplasts (Figure $5 \& 5 \mathrm{~b}$ ). The size of the individual palisade ranged from $158 \mu \mathrm{m}$ to 663 $\mu \mathrm{m}$ in length with a mean length of about $367 \mu \mathrm{m}$ (Figure $5 \mathrm{~b} \& 5 \mathrm{c}$ ). The major portion of mesophyll was occupied by the lacunar spongy tissues consisted of 3-4 layers of oval to rectangular cells, loosely arranged with wide intercellular spaces. Some of the spongy cells contained druses crystals and prismatic crystals of calcium oxalate. Mid rib of the lamina possessed traces of vascular bundles, but not differentiated into distinct metaxylem and protoxylem. The palisade ratio was found to be about 4. The contour of mid rib appeared slightly raised on the adaxial side with broadly semicircular on the abaxial side (Figure 5). Lamina was flat and much reduced in dimension. Midrib was composed of epidermis, collenchyma, mesophyll and vascular bundle. Just beneath the adaxial epidermis contained a patch of subepidermal collenchyma tissues, compraised of 4-5 rows of cells. Bicollacteral vascular bundle with the phloem aligned in between the xylem elements and a group of 30-35 bundles was found aligned in $\mathrm{V}$ shaped configuration at the middle of the parenchymatous ground tissue (Figure 5a).The major portion of the midrib was occupid by parenchymatous ground tissues.

\section{Microscopic evaluation of petiole}

The petiole had a characteristic contour with a deeply concave groove on the adaxial side and broadly circular on the abaxial side (Figure 6). A chlorenchyma zone consisted of 2-3 layers were found located beneath the epidermis, followed by a broad zone of parenchymatous tissues. A group of 10-15 vascular bundles was found aligned in crescent shape somewhat at the middle of the parenchymatous ground tissue (Figure $6 \mathrm{~b})$. Each vascular strand was separated from one another by wide areas of ground tissues. Xylem vessels were aligned in radial rows of 5-6 and encircling phloem on both adaxial and abaxal sides. Druses crystals of calcium oxalate (Figure $6 \mathrm{a} \& 6 \mathrm{~b}$ ) were found distributed in the phloem and parenchymatous cells of the ground tissues.

Epidermal characters

The epidermal peel showed stomata on both surfaces (amphistomatic). Stomata was anisocytic (Figure $7 \& 7$ a) type. Anticlinal walls of upper epidermal cells were straight and sinuate to wavy on the lower epidermis. The mean length and breadth of upper stoma were found to be $24.9 \mu \mathrm{m}$

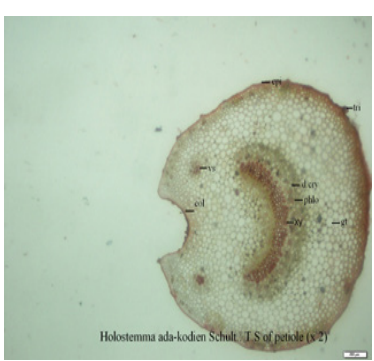

Figure 6: Holostemma adakodien Schult. T.S. of Petiole $(\times 2)$

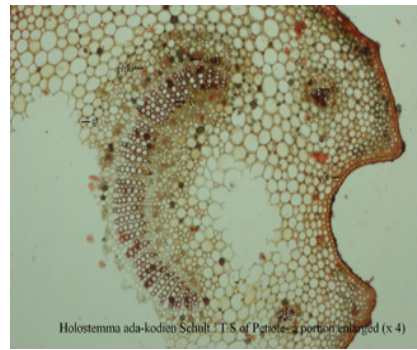

Figure 6a: Holostemma adakodien Schult. a portion of petiole enlarged $(\times 4)$

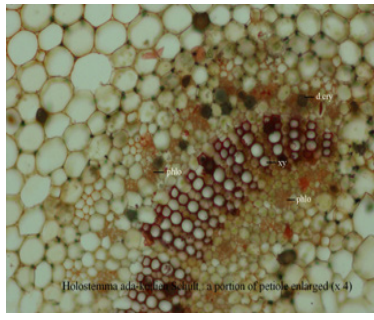

Figure 6b: Holostemma adakodien Schult. a portion of petiole enlarged $(\times 10)$ 


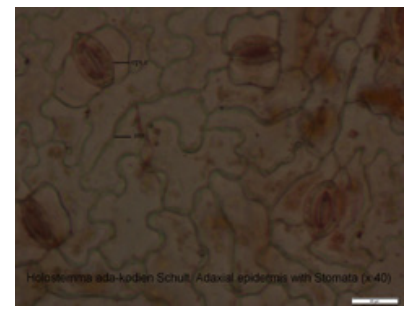

Figure 7: Holostemma adakodien Schult. Adaxial epidermis with stomata $(\times 40)$

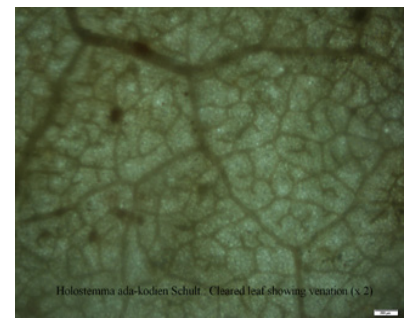

Figure 8: Holostemma adakodien Schult. Cleared leaf showing venation $(\times 2)$

and $15.4 \mu \mathrm{m}$ respectively and that of the lower stoma was $19.2 \mu \mathrm{m}$ and $9.9 \mu \mathrm{m}$. The mean Guard cell area (GCA) of lower surface was found to be $408.7 \mu \mathrm{m} .^{2}$ The number of adaxial epidermal cells per square millimeter area of the leaf was observed as 455.94 and that of the abaxial side was 372.16 . The stomatal index for the upper surface of the lamina was found to be 19.8 and the lower surface was 16.3 .

\section{Venation pattern}

Venation patterns of cleared leaves were studied and terminology used for the description of architecture is as per Hickey. ${ }^{14}$ Petiolate simple leaves with entire margins had major leaf venation pattern of campylodromous under low $(\times 2)$ magnification. Areolation was poorly developed, veinlet dichotomizing once branched (Figure 8) and marginal ultimate veins were of fimbriate type. The cleared leaves contained plenty of druses crystals of calcium oxalate, and crystals appeared strongly birefringent (Figure 8a) under polarized microscopy.

\section{Powder microscopy}

The dried leaves, root and stem of Holostemma ada-kodien Schult. were analysed for powder characteristics. Microscopic examination showed fragments of leaf epidermis having conspicuous venations (Figure 9) and anisocytic stomata, lamina with druses crystals of calcium oxalate under polarization microscopy appeared birefringent (Figure 9a). Stem powder showed fragment of parenchymatous tissues of the cortex (Figure $9 b$ ). Root powder showed group of stone cells (Figure 9c) with lignified secondary wall, forked lignified fibers (Figure 9d \& 9e) with narrow lumen, calcium oxalate crystals (Figure 9f) and starch grains. Starch grains

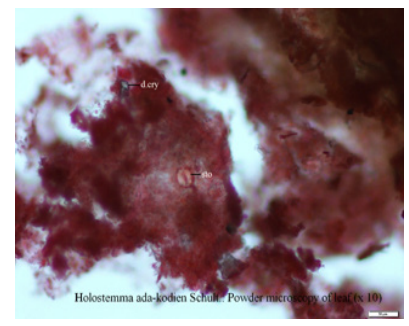

Figure 9: Holostemma ada-kodien Schult. Powder microscopy of leaf $(x$ 10)

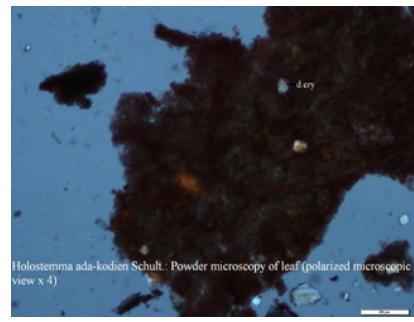

Figure 9a: Holostemma adakodien Schult. Powder microscopy of leaf (polarized $\times 4$ ).

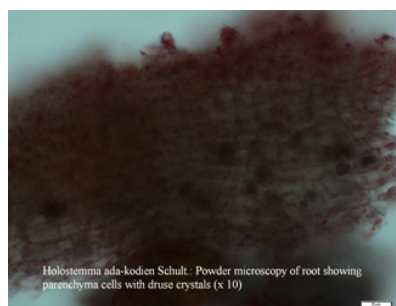

Figure 9b: Holostemma adakodien. Powder microscopy of stem-parenchyma cells(x10)

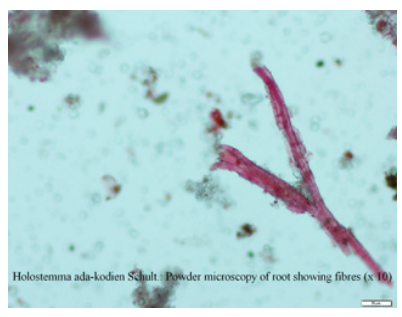

Figure 9d: Holostemma ada-kodien Schult. Powder microscopy of root- fibre (x10)

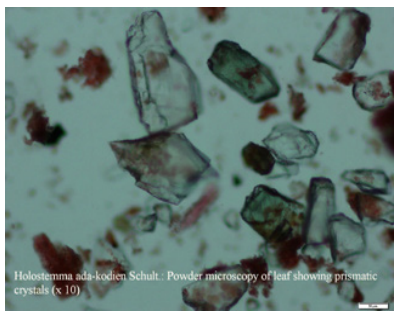

Figure 9f: Holostemma adakodien Schult. Powder microscopy of root showing prismatic crystals-polarized microscopy (x40)

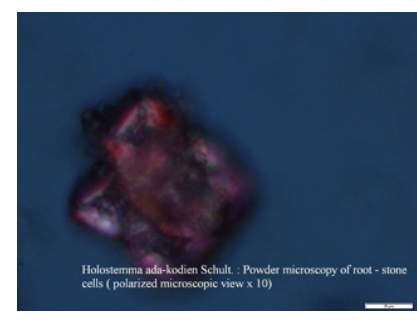

Figure 9c: Holostemma adakodien Schult. Powder microscopy of root- stone cells (polarized microscopic view (x10)

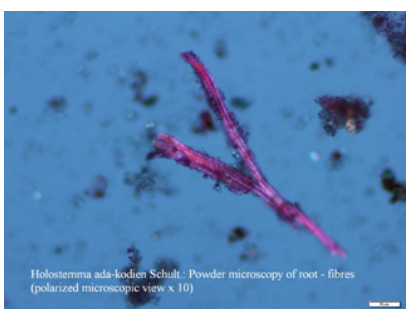

Figure 9e: Holostemma ada-kodien Schult. Powder microscopy of root- fibre (polarized microscopy (x10)

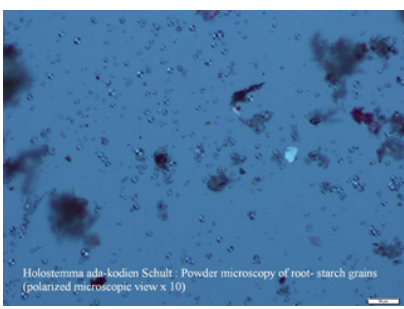

Figure 9g: Holostemma ada-kodien Schult. Starch grains-polarized microscopic view (x10).

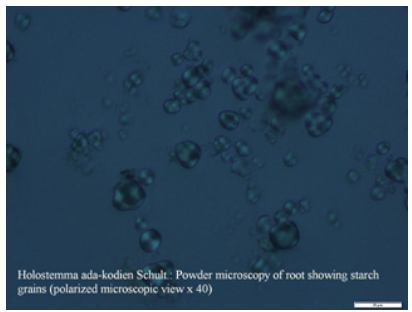

Figure 9h: Holostemma ada-kodien Schult. Starch grains-polarized microscopic view (x40). were of simple and compound types, when viewed under crossed polarized light starch grain showed centered extinction cross or 'Maltese cross' (Figure $9 \mathrm{~g} \& 9 \mathrm{~h}$ ), which indicates that the hilum centrally occupied in the grains.

\section{CONCLUSION}

The results of the present study suggest that the documented morphological descriptors and histo-anatomical markers delineated from the stem, root tuber, root and leaves of Holostemma ada-kodien Schult. Thus provide useful information for quality control parameters for the crude drugs. 


\section{ACKNOWLEGEMENT}

None.

\section{CONFLICT OF INTEREST}

\section{Author has declared that no conflict of interest exists.}

\section{ABBREVAITIONS USED}

ABX.E: Abaxialepidermis; ADAX.E: Adaxialepidermis; D.CRY: Druses Crystals; CHM: Chlorenchyma; CK, CR: Cork; CO: Cortex; COL: Collenchym; CRL, CRY: Crystal; CUT: Cuticle; EP, EPI.C: Epidermal cell; EPI: Epidermis; G.FR: Gelatinous fibre; GU.C: Guard cell; GT: Ground tissue; LA: Lamina; L.UP: Lower epidermis; MDR: Medullary rays; PAL: Palisade cell; PHO: Phloem; PI: Pith; SPO: Spongy parenchyma; S.PH: Secondary phloem; ST: Stomata; STO: Stone cell; STR: Starch grain; S.XY: Secondary xylem; TRI: Trichome; XY: Xylem; U.EPI: Upper epidermis; VB: Vascular bundle; WD: Wood.

\section{REFERENCES}

1. Khare CP. Indian Herbal remedies Rational Western Therapy, Ayurvedic and Other. C.P. Khare, eds. New York: Springer-Verlag;2004. https://doi.org/10.1007/9783-642-18659-2.

2. Sharma PC, Yelne MB, Dennis TJ. Database on Medicinal plants used in Ayurveda. Vol 2, eds. New Delhi: Central Council for Research in Ayurveda and Siddha (CCRS);2001.pp270-71.

3. Bawra B, Dixit M, Chouhan NS, Dixit VK, Saraf DK. Leptadenia reticulata A Rasayana Herb: A Review. Asian J Plant Sci. 2010;9(6):314-19. https://doi. org/10.3923/ajps.2010.314.319

4. Warrier PK, Nambiar VPK, Ramankutty. Indian Medicinal Plants: A compendium of 500 species. Vol. 3,Orient Longman; 1995

5. Ramiah N, Nair GA, Prasad NBR. Chemical composition of $H$. annulare $K$. Schum. J Sci Res Plant Med.1981;2(3):76-78.

6. Reddy DS, Muchandi IS, Rao SA, Pradeep HA, Kumar RK, Rao MS, Ibrahim M Effects of Holostemma anulare on the progression of diabetes induced by a high fructose diet in rats and diabetic C57B2/6Job/ob mice. Diabetes Metab Syndr Obes. 2010;3:87-94. https://doi.org/10.2147/DMSO.S9099; PMid:21437079 PMCid:PMC3047978

7. Sadasivam RK, Sridhr C, Jayaveera KN. In vitro anthelmintic activity of leaf extract of Shorea tumbuggaia Roxb. And Holostemma ada-kodien Schult. On (Pheretima posthuma) Indian Earth worm. J Pharm Clin Res.2014;7(suppl 2):95-

8. Avanapu SR, Dachani SR. Antihyperglycimic activity of Holostemma annularis K. Schum. Root extracts in Streptozotocin- induced diabetic Wistar rats. Indo Amer J Pharm Res.2013;3(7):5118-26.

9. Subramoniam A. Plants with Anti-Diabetes Mellitus Properties. CRS Press,
Boca Raton, New york: Taylor \& Francis. 2016;6:236. https://doi.org/10.1201/ b19653.

10. Sunil J, Krishna JY, Brahmachari PV. Hepatoprotective activity of Holostemma ada- kodien Shcult., extract against Paracetamol induced hepatic damage in Rats. European J Med Plants. 2015:6(1):45-54. https://doi.org/10.9734/ EJMP/2015/12117.

11. Girija TP, Rema Shree AB. Comparative histological and phytochemical studies of the raw drug Jivanti from different raw drug markets of Kerala. Int J Pharm Sci Res. 2016;7(5):2122-6.

12. Wallis TE. A text book of Pharmacognosy. 3 eds. London: J \& A Churchill; 1976

13. Franco C. Relation between chromosome number and stomata in Coffee. Bot Gaz. 1939;100(4):817-27. https://doi.org/10.1086/334832.

14. Hickey LJ. Classification of the architecture of dicotyledeneous leaves. Am J Bot. 1973;60:17-33. https://doi.org/10.2307/2441319.

15. Metcalfe CR, Chalk L. Anatomy of the Dicotyledons: Wood structure and conclusion of the General Introduction. 2nd ed. Vol 2.Great Britain: The Clarendon, Oxford; 1985.

16. Carlquist S, Hoekman DA. Ecological wood anatomy of the woody Southern Californian Flora. IAWA Bull.1985;6(4):319-47. https://doi.org/10.1163/2294193290000960.

17. Sudhakaran MV. Botanical Pharmacognosy of Andrographis paniculata (Burm.f) Wall. Ex. Nees. Phcog J. 2012;4(32):1-10. https://doi.org/10.5530/pj.2012.32.1.

18. Sudhakaran MV. Pharmacognostic and HPTLC finger print profile of the root of Aristolochia indica Linn and quantification of the marker compound. European $J$ Med Plants. 2014:4:1113-24. https://doi.org/10.9734/EJMP/2014/9570.

19. Sudhakaran MV. Botanical Pharmacognosy of the fruit of Embelia ribes Burm.F. J Pharmacogn Nat Prod. 2015;1(103):9-15

20. GorshkovaTA, Gurjanov OP, Mikshina PV, Ibragimova NN, Mokshina NE, Salnikov $\mathrm{V}$, et al. Specific type of secondary cell wall formed by plant fibers. Russian J Plant Physiol. 2010;57(3):328-41. https://doi.org/10.1134/S1021443710030040.

21. Wyatta SE, Sederoffb R, Flaishmanc MA, LevYadund S. Arabidopsis thaliana as a model for gelatinous fiber formation. Russian J Plant Physiol. 2010:57(3)363-7. https://doi.org/10.1134/S1021443710030076

22. Jin $\mathrm{H}$, Kwon M. Mechanical bending- induced tension wood formation with reduced lignin biosynthesis in Liriodendron tulipifera. JWood Sci. 2009:55(6):4018. https://doi.org/10.1007/s10086-009-1053-1.

23. Hu WJ, Harding SA, Lung J, Popko JL, Ralph J, Stokke DD, Tsai CJ, Chiang VL. Repression of lignin biosynthesis promotes cellulose accumulation and growth in transgenic trees. Nat Biotechnol.1999;17(8):808-12. https://doi. org/10.1038/11758; PMid:10429249

24. Bowling AJ, Vaughn KC. Immunocytochemical characterization of tension wood: gelatinous fibers contain more than just cellulose. Am J Bot. 2008;95(6):65563. https://doi.org/10.3732/ajb.2007368; PMid:21632390.

25. Angyalossy $\vee$, Angeles G, Pace MR, Lima AC, Dias-Leme CL, Lohmann LG, Madero-Vega C. An overview on the anatomy, development and evolution of the vascular system of lianas. Plant Ecol Divers.2012;5(2):167-82. https://doi.or $\mathrm{g} / 10.1080 / 17550874.2011 .615574$.

26. Ewers FW, Carlton MR, Fisher JB, Kolb KJ, Tyree MT. Vessel diameters in roots versus stems of tropical lianas and other growth forms. IAWAJ.1997;18(3):261-79. https://doi.org/10.1163/22941932-90001490.

27. Wagner GJ. Secreting glandular trichomes: more than just hairs. Plant Phys 1991;96: 675-79. https://doi.org/10.1104/pp.96.3.675. 


\section{SUMMARY}

- Holostemma ada-kodien Schult. is an important medicinal plant with rejuvenating properties used in Ayurvedasystem of medicine for promoting vitality and life. The root tuber of this rasayana plant is often considered as thesource of Jivanti.

- The plant is highly specialized for the richness of a diverse array of amino acids such as alanine, aspartic acid, glycine, serine, thereonine, valine, and terpenoid sugars.

- Amphistomatic, anisocytic stomata, small palisade ratio, small stomatal index, distribution of gelatinous fibers as 'concentric white rings' in stem cortex, druses crystals of calcium oxalate in various tissue systems, contour of the midrib, fissured secondary xylem as the spokes of a wheel in cross section of the root tuber are features characteristic of the taxon.

- The anatomical markers, quantitative microscopy characteristics were delineated from the stem, root tuber, root and leaves of Holostemmaada-kodien Schult. may provide useful information for regulatory aspects of quality control measures and also help to distinguish the source drug from the allied, spurious and adulterant species.

\section{ABOUT AUTHORS}

(2)

$\rightarrow$

Madathilparambil Vasu Sudhakaran (M.V.Sudhakaran): Has received the Ph.D Degree of the University of Kerala. Currently he is positioned as Associate Professor, UGC-Academic Staff College of the University of Calicut. He is a research guide in Botany under the faculty of Science. His research interests include genetic diversity analysis, genetic effects of inbreeding, and the pharmacognostical and phytochemical aspects of medicinal plants.

Cite this Article: Vasu SM. Botanical Pharmacognosy of Holostemma ada-kodien Schult. Pharmacogn J. 2017;9(2):163-70 